\title{
Gorontalo
}

Journal of Government and Political Studies

Volume 3 - NO. 2-Oktober 2020

P-ISSN: 2614-2120 E-ISSN: 2614-2104

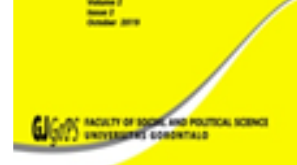

\section{Analisis Dampak Kasus Kebakaran Hutan di Indonesia Terhadap Hubungan Diplomatik Indonesia dengan Malaysia dan Singapura}

\author{
Nisrina Bilqis \\ Program Studi Magister Ilmu Politik, Universitas Diponegoro \\ J. Prof. Sudarto No.13, Tembalang, \\ Semarang, Indonesia 50275
}

Received: 20th August 2020; Revised: 16th September 2020; Accepted: 16th September 2020

\begin{abstract}
This research aims to analyse the impact arising from Karhutla (forest and land fires) in Indonesia to Indonesia's diplomatic relations with Malaysia and Singapore. This is due to the case of Karhutla that occur in Indonesia to make a detrimental impact not only for Indonesia, but the smoke of the appeal raises losses for the other country, especially for Malaysia and Singapore. Losses are inflicted not only in terms of health, but in other aspects make the economic activity disturbed. This led to protests from the Malaysian and Singaporean governments, which assumed that the Indonesian Government was unable to resolve the Karhutla case which occurred almost annually. Conditions were considered increasingly complicated, when the Indonesian Government refused assistance from the Malaysian and Singaporean governments. In this study, the concept used was about diplomatic relations, in which Indonesia tends to do diplomacy by implementing Disaster Diplomacy as an effort to minimize the conflict arising from karhutla cases that have occurred since long time ago. Research methods are implemented using qualitative research methods using secondary data sources. The results show that Karhutla had an impact on the economic and social sectors, but had no effect on diplomatic relations. Although Karhutla increased the debate between Indonesia and Malaysia and Indonesia with Singapore which considered that Indonesia could not handle the karhutla case so that from protests posed by the Malaysian and Singaporean governments influenced Indonesia's image of international view as it was considered weak in handling Karhutla in Indonesia.
\end{abstract}

Keyword: forest and landfire; diplomatic relations

\begin{abstract}
ABSTRAK
Penelitian ini bertujuan untuk menganalisis dampak yang timbul dari kasus karhutla (Kebakaran Hutan dan Lahan) di Indonesia terhadap hubungan diplomatik Indonesia dengan Malaysia dan Singapura. Hal ini didasari kasus karhutla yang terjadi di Indonesia memberikan dampak yang merugikan bukan hanya bagi Indonesia saja, tetapi asap kabutnya menimbulkan kerugian bagi negara tetangga, khususnya bagi Malaysia dan Singapura. Kerugian yang ditimbulkan bukan hanya dalam hal kesehatan, tetapi dalam aspek lain membuat kegiatan perekonomian terganggu. Hal tersebut menimbulkan protes dari pemerintah Malaysia dan Singapura, yang menganggap bahwa
\end{abstract}


pemerintah Indonesia tidak mampu menyelesaikan kasus karhutla yang terjadi hampir tiap tahunnya. Kondisi dianggap semakin rumit, ketika pemerintah Indonesia menolak bantuan dari pemerintah Malaysia dan Singapura. Dalam penelitian ini, konsep yang digunakan adalah mengenai hubungan diplomatik, dimana Indonesia cenderung melakukan diplomasi dengan menerapkan Disaster Diplomacy sebagai upaya meminimalisir konflik yang ditimbulkan dari kasus karhutla yang sudah terjadi sejak lama. Adapun metode penelitian yang diterapkan adalah dengan menggunakan metode penelitian kualitatif dengan menggunakan sumber data sekunder. Hasil penelitian ini menunjukkan meskipun Karhutla berdampak pada sektor ekonomi dan sosial, akan tetapi tidak berpengaruh ke hubungan diplomatiknya. Meskipun begitu Karhutla menimbulkan perdebatan antara Indonesia dengan Malaysia dan Indonesia dengan Singapura yang menganggap Indonesia tidak mampu dalam menangani kasus karhutla sehingga dari protes yang dilayangkan oleh pemerintah Malaysia dan Singapura tersebut mempengaruhi citra Indonesia di mata Internasional karena dianggap lemah dalam menangani karhutla di Indonesia

Kata kunci: karhutla Indonesia; hubungan diplomatik

\section{PENDAHULUAN}

Sejarah membuktikan bahwa sifat hubungan antarnegara dengan negara lain senantiasa berubah-ubah menurut perubahan masa dan keadaan, tetapi cara memelihara dan menghidupkan perhubungan salah satunya dengan mempergunakan cara diplomasi. Adapun yang dimaksud diplomasi adalah kecakapan dalam pengelolaan hubungan, dalam melakukan perjanjian dengan orang lain sehingga urusan terselesaikan dengan lancar. ${ }^{1}$ Hubungan diplomatik akan terus berkembang kepada kebutuhan suatu kelompok dengan kelompok lainnya dan dewasa ini telah berkembang menjadi hubungan yang lebih luas antara satu negara dengan negara lain. Permasalahan yang dikaji pun lebih bervariasi mulai dari diplomasi ekonomi hingga pada hubungan diplomatik dalam rangka membentuk diplomasi penanggulangan bencana. ${ }^{2}$

Pada buku karya Sumaryo Suryokusumo, tertulis bahwa Hubungan Diplomatik merupakan hubungan yang dijalankan antara negara satu dengan negara lainnya untuk saling memenuhi kebutuhan masing-masing negara, hal ini sudah dilakukan sejak berabad-abad yang lalu. Sama halnya Indonesia dengan Malaysia dan Singapura, hubungan diplomatik telah dijalankan sejak lama, bahkan praktik berdiplomasi telah dilakukan oleh antarmasyarakat kedua negara sebelum kemerdekaan masing-masing negara. Untuk dapat menjalankan hubungan diplomatik dengan negara lain perlu adanya pengakuan (recognition) terlebih dahulu terhadap negara tersebut, terutama oleh negara yang akan menerima perwakilan diplomatik suatu negara (Receiving State). Tanpa adanya pengakuan terhadap negara tersebut, maka pembukaan hubungan dan perwakilan diplomatik tidak bisa dilakukan. ${ }^{3}$

Di dalam prakteknya, untuk menjalankan hubungan diplomatik diperlukan adanya perwakilan diplomatik dari tiap-tiap negara. Perwakilan-perwakilan tersebut akan dipilih oleh negara yang mengutusnya dan akan menjalankan diplomasi sebagai salah satu cara komunikasi yang biasanya dilakukan antara berbagai pihak termasuk negosiasi antara wakil-wakil yang sudah diakui. ${ }^{4}$ Jika suatu negara telah menyetujui pembukaan hubungan diplomatik dengan negara

\footnotetext{
1 J. Badri, Perwakilan Diplomatik dan Konsuler, Tintamas, Jakarta, 1960, hlm. 19.

2 Ibid

3 Sumaryo Suryokusumo, Hukum Diplomatik dan Konsuler Jilid I ,Tatanusa, Jakarta,2013, hlm.8.

${ }^{4}$ Konvensi Wina 1961, Pasal 2
} 
lain melalui suatu instrumen atas dasar asas timbal balik (principle of reciprocity) dan asas saling menyetujui (mutual consent), 5 negara-negara tersebut sudah harus memikirkan pembukaan suatu perwakilan diplomatik dan penyusunan keanggotaan perwakilan tersebut baik dalam tingkatannya maupun jumlah anggota staf perwakilan yang telah disetujui bersama atas dasar kewajaran dan kepantasan (reasonable and normal). ${ }^{6}$

Pasca kemerdekaan Malaysia pada tahun 1957, Malaysia secara resmi menjalin hubungan diplomatik dengan Indonesia. Walaupun demikian, hubungan antarmasyarakat sudah terjalin lama jauh sebelum lahirnya negara Malaysia dan Indonesia. ${ }^{7}$ Disamping itu, hubungan diplomatik Indonesia dengan Singapura, tidak jauh berbeda dengan Indonesia dan Malaysia. Tahun 2017 menandai peringatan emas 50 tahun persahabatan Indonesia dan Singapura. Hubungan ini berawal sejak 7 September 1967, ketika Menlu RI Adam Malik dan koleganya S. Rajaratnam secara resmi mengawali hubungan diplomatik kedua negara. Singapura adalah investor terbesar di Indonesia. Pada Juli 2017, Badan Koordinasi Penanaman Modal (BKPM) mencatat, Penanaman Investasi Asing (PMA) terbesar berasal dari Negeri Singa, yakni senilai US\$ 3,66 miliar atau Rp 48,69 triliun. ${ }^{8}$

Perkembangan hubungan diplomatik antara Indonesia dengan Malaysia dan Singapura beberapa waktu terakhir dianggap berada dalam kondisi kurang harmonis, hal tersebut didasari karena kasus bencana kebakaran hutan dan lahan (selanjutnya ditulis "karhutla") di Indonesia mengundang reaksi dari Pemerintah Malaysia dan Singapura yang menuding Indonesia tidak serius mengatasi karhutla sehingga asapnya sampai ke Malaysia. Indeks pencemaran udara Malaysia mencatat kualitas udara pada tingkat tidak sehat. Malaysia menuding kabut asap berasal dari kebakaran hutan yang terjadi di Sumatra dan Kalimantan. Hampir setiap musim kemarau Malaysia menuding Indonesia mengirim asap ke Malaysia dan Singapura. ${ }^{9}$

Kabut asap bisa dikatakan sebagai bencana tahunan bagi Indonesia. Hasil dari analisis Greenpeace, 3.403.000 hektar (ha) lahan terbakar antara tahun 2015 sampai dengan 2018 di Indonesia, menurut hasil analisis burn scar (bekas terbakar) dari data resmi pemerintah. Pada tahun 2015 saja, lebih dari 2.600.000 ha lahan mengalami kebakaran. Kebakaran yang melanda Indonesia pada tahun 2015 dianggap sebagai salah satu bencana lingkungan hidup terbesar di abad 21, hingga saat ini. ${ }^{10}$

\footnotetext{
5 Sumaryo Suryokusumo, Op. Cit., hlm.53

6 Konvensi Wina 1961, Pasal 22 (1)

7 Maksum,A \& Bustami, R. (2014). Ketegangan hubungan Indonesia Malaysia dalam isu Tarian Pendet,Kajian Malaysia. Kajian Malaysia: Journal of Malaysian Studies

8 Elin Yunita Kristanti, Masa Depan Hubungan RI-Singapura Menurut Menlu Singapura diakses dari https://www.liputan6.com/global/read/3121144/masa-depan-hubungan-ri-singapuramenurut-menlu-negeri-singa Pada 20 Januari 2020 Pukul 17.06 WIB.

9 Liputan 6, Kabut Asap Memanaskan Hubungan Diplomatik Indonesia dan Malaysia?, diakses dari https://www.liputan6.com/news/read/4062487/kabut-asap-memanaskan-hubungandiplomatik-indonesia-dan-malaysia. Pada 25 Maret 2020 Pukul 20.00 WIB.

10 Greenpeace Indonesia, Briefer - Krisis Kebakaran Hutan dan Lahan di Indonesia: Perusahaan Kelapa Sawit dan Bubur Kertas dengan Area Kebakaran Terbesar Tak Tersentuh Hukum diakses dari https://www.greenpeace.org/indonesia/publikasi/3795/briefer-krisis-kebakaran-hutan-danlahan-di-indonesia-perusahaan-kelapa-sawit-dan-bubur-kertas-dengan-area-kebakaran-terbesartak-tersentuh-hukum/ Pada 1 Februari 2020 Pukul 21.00 WIB.
} 
Asap dari karhutla yang terjadi di beberapa provinsi di Indonesia, telah menyeberang ke Malaysia dan Singapura serta mengganggu aktivitas masyarakat di dua negara itu. Indonesia, Malaysia, dan Singapura, dan negara ASEAN lain adalah pihak dalam Persetujuan ASEAN tentang Pencemaran Asap Lintas-Batas (Agreement on Transboundary Haze Pollution) yang ditandatangani pada tahun 2002. Hal tersebut bisa dikatakan sebagai bentuk dari Disaster Diplomacy, dimana hal tersebut dianggap sebagai diplomasi yang sangat relevan untuk menyelesaikan kasus ini, meskipun Disaster Diplomacy merupakan konsep yang relatif baru. ${ }^{11}$ Disaster Diplomacy yang dijalankan oleh pemerintah Indonesia dalam menangani bencana khususnya kabut asap, merupakan cara yang sangat efektif untuk dilakukan dalam rangka memperbaiki citra Indonesia yang dianggap kurang maksimal dalam menangani permasalahan kabut asap lintas batas yang disebabkan oleh karhutla dan sebagai upaya untuk menjaga hubungan diplomatik yang tensinya turun naik dengan Malaysia dan Singapura ketika kasus karhutla terjadi tiap tahunnya.

Dalam perjanjian itu disebut bahwa negara yang membutuhkan bantuan memadamkan api karena kebakaran hutan, bisa meminta bantuan negara anggota ASEAN lainnya yang bersedia membantu. Namun pada kenyataannya pemerintah Indonesia menolak tawaran bantuan yang diberikan oleh pemerintah Malaysia dan Singapura. ${ }^{12}$ Penolakan tersebut didasari karena Indonesia mampu menyelesaikan persoalan kebakaran hutan sendiri, Juru bicara Kementerian Lingkungan Hidup dan Kehutanan (KLHK), Jati Witjaksono, mengatakan Indonesia tengah menjaga martabatnya dengan tidak meminta bantuan negara lain. ${ }^{13}$

Adapun beberapa penelitian terdahulu yang relevan dengan penelitian yang dilakukan diantaranya adalah Jurnal karya Laode Muhamad Fathun ${ }^{14}$ menjelaskan bahwa terjadinya kebakaran hutan banyak disebabkan oleh beberapa faktor, faktor alam dan atau faktor non-alam maupun faktor manusia sehingga mengakibatkan timbulnya korban jiwa manusia, kerusakan lingkungan, kerugian harta benda, dan dampak psikologis. Definisi tersebut menyebutkan bahwa bencana disebabkan oleh faktor alam, non alam, dan manusia.Oleh karena itu, Undang-Undang Nomor 24 Tahun 2007 tersebut juga mendefinisikan mengenai bencana alam, bencana non-alam, dan bencana social, yang dimana dalam jurnal ini juga menyinggung dampak yang ditimbulkan menyebabkan terjadinya polusi asap yang menimpah wilayah Indonesia dan sejumlah negara-negara ASEAN. Dari penelitian Laode, ditemukan betapa buruknya tata kelola dan kesiapsiagaan pemerintah baik pusat ataupun daerah dalam menjaga bencana kebakaran. Jurnal lain karya Kunto15, jurnal ini menjelaskan terjadinya karhutla merupakan ancaman bagi seluruh aspek

\footnotetext{
11 I Kelman., Disaster Diplomacy: How Disaste Affect Peace and Conflict, Routledge, London, 2011, hlm 5 .

12 Callistasia Wijaya, Kebakaran hutan: Ditawari Malaysia dan Singapura bantuan, Indonesia sebut nanti 'dilecehkan, ah gitu aja minta bantuan', diakses dari https://www.bbc.com/indonesia/indonesia-49765217 pada 2 Februari 2020.

13 Ibid

14 Loade Muhamad Fathun, (2016). Bencana Hutan dalam Hubungan Internasional. Andalas Journal of International Studies, Vol.5 No.1

15 Kunto Arief Wibowo,(2019). Manajemen Penanganan Kebakaran Hutan dan Lahan (Karhutla) Guna Peningkatan Ekonomi Kerakyatan. Jurnal Studi Sosial dan Politik, Vol. 3, No. 1.
} 
kehidupan bermasyarakat, berbangsa dan bernegara. Hal tersebut terlihat pemikiran yang diambil oleh Kunto yang menyatakan bahwa adanya karhutla mempunyai korelasi dengan pemanfaatan lahan yang ada, ataupun karena ketidakmampuan mengatasi masalah lahan mereka. Dalam penelitian ini cenderung lebih membahas kepada manajemen penanganan karhutla di Indonesia yang menjadi faktor internal merebaknya asap ke negara-negara tetangga, sedangkan penelitian ini cenderung lebih mengkaji mengenai respon dan dampak yang ditimbulkan dari karhutla yang terjadi di Indonesia terhadap hubungan diplomatik dengan negara-negara tetangga khususnya Malaysia dan Singapura.

Penelitian terdahulu lainnya dilakukan oleh Anih Sri16, Anih menyatakan bahwa karhutla memberikan kerugian yaitu pada sektor kesehatan, akibat terpapar kabut asap terjadi peningkatan kasus penyakit terutama pasien ISPA, sedangkan pada sektor ekonomi eksternal negatif asap akan menimbulkan pengaruh yang sangat besar terhadap perekonomian daerah setempat dan juga nasional. Dampak kabut juga mengganggu sektor transportasi karena mengganggu jarak pandang, sehingga perjalanan darat, laut dan udara. Penelitian milik Anih Sri lebih berfokus pada penanganan karhutla di Indonesia dan juga memaparkan beberapa upaya yang telah dilakukan oleh pemerintah Indonesia dalam penanganan karhutla. Dalam Jurnal Anih Sri ini cenderung lebih menjabarkan penanganan dan juga kendala yang dialami oleh pemerintah Indonesia dalam menangani karhutla.

\section{METODE PENELITIAN}

Adapun metode penelitian yang digunakan adalah metode kualitatifdeskriptif. Hal ini didasari karena dalam metode penelitian kualitatif objek dalam penelitian ini yakni mengenai dampak karhutla terhadap hubungan diplomatik Indonesia dengan Malaysia dan Singapura dimana hal ini merupakan suatu realitas sosial yang dipandang sebagai suatu gejala atau fenomena yang holistik, kompleks, dan penuh makna. Oleh sebab itu, hal ini tidak bisa diukur menggunakan metode penelitian kuantitatif. ${ }^{17}$

Teknik pengumpulan data dengan menggunakan data sekunder yang dilakukan melalui studi kepustakaan yaitu mencari serta mempelajari data-data seperti dari buku, dokumen perjanjian, majalah, surat kabar dan dari dokumen tertulis, dan sumber internet yang terkait dengan topik penelitian ini. Adapun Teknik analisa yang digunakan adalah teknik analisa induktif. Peneliti melakukan analisis data kualitatif secara interaktif dan berlangsung secara terus menerus sampai tuntas, sehingga datanya menjadi jenuh. ${ }^{18}$

\section{HASIL DAN PEMBAHASAN}

\section{Penyebab dan Dampak Karhutla di Indonesia}

Wetlands International menyatakan bahwa berdasarkan fakta yang ada, hampir semua kebakaran hutan di Indonesia disebabkan oleh kegiatan manusia, baik disengaja atau tidak disengaja, dan belum ada bukti kebakaran

\footnotetext{
16 Anih Suryani, (2012). Penanganan Asap Kabut Akibat Kebakaran Hutan Di Wilayah Perbatasan Indonesia. Jurnal DPR, Vol 3, No 1.

17 Sugiyono, Metode Penelitian Kuantitatif Kualitatif dan R \& D, Alfabeta, Bandung, 2014, hlm 9.

18 Sugiyono, Ibid., 243.
} 
yang terjadi secara alami. ${ }^{19}$ Herry Purnomo, seorang peneliti lembaga Center for International Forsty Research, mengatakan bahwa banyak pihak mendapat untung besar dari kebakaran. Dia menemukan bahwa lahan kerap sengaja dibakar demi mengklaim kepemilikan. Hal inilah yang terjadi di Kalimantan. Setelah kebakaran berhasil dipadamkan, tidak lama berselang, lahan kosong bekas kebakaran sudah berisi jajaran pohon kelapa sawit. ${ }^{20}$ Dengan demikian kita dapat mengatakan bahwa yang terjadi sebenarnya adalah pembakaran hutan dan lahan. Salah satu tujuan dari pembakaran hutan dan lahan ini adalah untuk pembukaan lahan perkebunan.

Dampak kebakaran hutan dan lahan yang paling menonjol adalah terjadinya kabut asap yang sangat mengganggu kesehatan masyarakat dan sistem transportasi sungai, darat, laut, dan udara. Secara sektoral dampak kebakaran ini mencakup sektor perhubungan, kesehatan, ekonomi, ekologi dan sosial, termasuk citra bangsa di mata negara tetangga dan dunia. ${ }^{21}$ Kabut asap yang terjadi di beberapa wilayah di Indonesia sendiri sampai merambah ke lintas negara tetangga salah satunya adalah Malaysia. Dampak yang langsung diterima masyarakat mulai dari gangguan pernapasan sampai melumpuhtotalkan aktivitas masyarakat karena kabut asap, hal ini didasari Kabut asap yang dihasilkan dari kebakaran hutan di Indonesia dari tahun ke tahun makin akrab sebagai agenda tahunan bagi negara tetangga dan hal ini disertai pula dengan dampak ekonomis yang dihasilkan dari kabut asap tersebut. ${ }^{22}$ Kabut asap ini bukan kasus baru yang ada di indonesia, sudah puluhan tahun isu asap selalu menjadi perbincangan yang mengharuskan pemerintah melakukan penanganan yang cepat dan tepat untuk mengatasi permasalahan ini sehingga tidak sampai menimbulkan dampak lain yang luar biasa.

Bagi Malaysia, dilihat dari aspek sosial-ekonomi adanya kabut asap yang berasal dari Indonesia membuat pemerintah Malaysia membuat kebijakan dengan terpaksa menutup lebih dari seribu sekolah karena kabut asap akibat kebakaran hutan dan lahan di kawasan kian parah. ${ }^{23} \mathrm{Hal}$ ini didasari karena kualitas udara yang dihasilkan dari kabut asap sangatlah berbahaya, sehingga dapat menimbulkan berbagai penyakit, seperti diantaranya infeksi saluran pernapasan, sakit mata dan batuk sebagai akibat dari asap kebakaran. Selain itu, Kebakaran gambut juga menyebabkan rusaknya kualitas air, sehingga air menjadi kurang layak untuk diminum. Untuk meminimalisir hal tersebut, Kementerian Pendidikan Malaysia merilis surat penutupan sekolah setelah menerima laporan bahwa kualitas udara di beberapa daerah mencapai tingkat "sangat tidak sehat". Merujuk pada data Kementerian Pendidikan Malaysia, negara bagian yang terkena dampak paling besar adalah Selangor, di mana 538

\footnotetext{
19 Wibisono, et al, Panduan Rehabilitasi dan Teknik Silvikultur di Lahan Gambut, Wetlands International-IP, Bogor, 2005.

20 Greenpeace Indonesia. 2015a. "Greenpeace Mengekspos Hutan Gambut Terbakar yang Ditanami Kelapa Sawit", http://www.greenpeace.org/seasia/id/press/releases/Greenpeace-mengeksposhutan-gambut-terbakar-yang-ditanami-kelapa-sawit

${ }^{21}$ Hermawan, W. 2006. Dampak Kebakaran Kebun dan Lahan terhadap Lingkungan Hidup. Dinas Perkebunan Provinsi Kalimantan Barat.

22 Deny Bram. Pertanggungjawaban Indonesia Terhadap Pencemaran Kabut Asap Di Ka W As An Asean (Peodekatan Economic Analysis Of Law)

23 CNN Indonesia. "Kemelut Kabut Asap Malaysia Tutup Sekolah". Diakses dari https://www.cnnindonesia.com/internasional/20190918145922-106-431599/kemelut-kabutasap-malaysia-tutup-1200-sekolah
} 
sekolah ditutup. ${ }^{24}$ Di ibu kota pemerintahan Malaysia, Putrajaya, 25 sekolah ditutup usai Air Pollution Index (API) dilaporkan melebihi 200.

Berdasarkan indicator Air Pollution Index (API), tingkat polusi 0-50 mengindikasikan kualitas udara bagus, 51-100 sedang, 101-200 tidak sehat, 201-300 sangat tidak sehat, dan $300 \mathrm{ke}$ atas berarti berbahaya. Kualitas udara di sejumlah wilayah lain di Malaysia juga mencapai tingkat tidak sehat. Pemerintah setempat pun memutuskan untuk menutup sekolah, termasuk yang berada di Kuala Lumpur. Sementara itu, 337 sekolah di Serawak juga tak beroperasi. Dari ratusan sekolah tersebut, 81 di antaranya merupakan sekolah dasar, sementara sisanya gabungan dari sekolah-sekolah menengah.

Dikutip dalam laman CNBC Indonesia September 2019 lalu,Singapura menyatakan turut terkena imbas kebakaran hutan RI. Negara ini mengatakan kondisi udaranya bisa mencapai tingkat tidak sehat dalam 24 jam ke depan jika angin terus menghembuskan asap kebakaran hutan dari Indonesia. Singapura juga telah menghimbau warganya untuk segera memeriksakan diri ke dokter apabila merasa mengalami gangguan akibat asap. Terutama untuk kelompok rentan seperti anak-anak, orang tua dan penderita penyakit jantung dan paru. ${ }^{25}$ F1 GP Singapura rencananya akan dilangsungkan September 2019 lalu. Namun karena kabut asap mulai tersebar di Singapura, masyarakat khawatir polusi udara mengganggu kesehatan dan mengurangi kemeriahan ajang balap motor dunia tersebut. Meski begitu, balapan masih akan digelar walaupun kabut asap tipis masih mengotori udara Singapura. "Agensi-agensi pemerintahan Singapura bekerja erat dengan penyelenggara balapan untuk memastikan balapan dan hiburan ini tetap menarik, sambil tetap memerhatikan pada kesehatan dan kondisi kebaikan setiap pengunjung. Ini termasuk menyiapkan skenario jika asap kabut memburuk," kata Direktur Eksekutif Singapore Tourism Board (STB), Jean Ng. ${ }^{26}$ di Singapura, kualitas udara sedikit memburuk dibandingkan Malaysia. Menurut Airvisual, udara di Singapura memiliki angka 103 dengan PM2.5 dan kualitas 36.5. Artinya udara sedikit tidak sehat.

Pencemaran udara akibat kebakaran hutan bertentangan dengan prinsipprinsip hukum lingkungan internasional. Salah satu prinsip adalah "Sie utero tua ut alienum non leades" yang menentukan bahwa suatu negara dilarang melakukan atau mengijinkan dilakukannya kegiatan yang dapat merugikan negara lain, good neighbourliness pada intinya prinsip itu mengatakan kedaulatan wilayah suatu negara tidak boleh diganggu oleh negara lain. Dampak karhutla ini menyebabkan Singapura melakukan protes, hal ini didasarkan pada alasan bahwa kabut asap tersebut telah menimbulkan gangguan terhadap kesehatan masyarakat, perekonomian serta pariwisata mereka. ${ }^{27}$

\footnotetext{
24 Ibid

25Rehia Sebayang. "Lagi Malaysia Negara ini Terimbas Kebakaran Parah Hutan RI". Diakses dari https://www.cnbcindonesia.com/news/20190910160919-4-98391/lagi-malaysia-negara-initerimbas-kebakaran-parah-hutan-ri

26Fellyanda Suci Agiesta."Derita Malaysia dan Singapura Diserang Kabut Asap dari Indonesia". Diakses dari https://www.merdeka.com/dunia/derita-malaysia-dan-singapura-diserang-kabutasap-dari-indonesia.html

27 Asdar. (2012). Transboundary Haze Pollution Di Malaysia Dan Singapura Akibat Kebakaran Hutan Di Provinsi Riau Ditinjau Dari Hukum Lingkungan Internasional. Jurnal Ilmiah Universitas Tadulako.
} 


\section{Dampak Karhutla Terhadap Hubungan Diplomatik Indonesia dengan Malaysia dan Singapura}

Lingkungan hidup merupakan salah satu komponen penting dalam kehidupan manusia. Selain menjadi tempat tinggal, lingkungan hidup juga menjadi penyedia sumber daya alam yang menjadi pemenuh kebutuhan manusia. Salah satu bagi lingkungan hidup adalah hutan yang harus tetap terjaga. Permasalahan kabut asap ini menjadi masalah internasional karena kasus ini menimbulkan pencemaran di negara-negara tetangga (transboundary pollution) sehingga mereka mengajukan protes terhadap Indonesia atas terjadinya masalah ini. ${ }^{28}$

Protes yang dilakukan oleh pemerintah Malaysia ini dipandang wajar, hal ini dikarenakan Indonesia merupakan negara anggota dari Perjanjian ASEAN tentang Pencemaran Asap Lintas Batas, dimana perjanjian ini adalah Perjanjian yang membahas mengenai pengaturan regional pertama di dunia yang mengikat sekelompok negara yang bersebelahan untuk mengatasi polusi asap lintas batas yang dihasilkan dari kebakaran lahan dan hutan. Namun, pada kenyataan hingga tahun 2019 lalu, karhutla masih saja terjadi dan Indonesia dianggap lemah dalam mencegah bahkan menanggulangi kasus karhutla. ${ }^{29}$

Persetujuan antara Malaysia dan Indonesia tentang Pencemaran Asap Lintas Batas Pencemaran kabut lintas batas adalah masalah besar yang mempengaruhi lingkungan dan kesehatan manusia di kawasan ASEAN. Negaranegara anggota ASEAN untuk merumuskan suatu panduan dan komitmen hukum secara bersama-sama yang dituangkan dalam suatu perjanjian yang berjudul ASEAN Agreement on Transboundary Haze Pollution (Persetujuan ASEAN tentang Pencemaran Kabut Asap Lintas Batas) yang mengatur pendistribusian tanggung jawab dan penanganan pencemaran kabut asap pada kawasan regional Asia Tenggara. Perjanjian ini ditandatangani oleh 10 Negara peserta ASEAN pada Juni 2002, dan kemudian came into force pada 25 November 2003. ${ }^{30}$ AATHP adalah salah satu bentuk perjanjian internasional di bidang lingkungan hidup. Perjanjian internasional adalah salah satu sumber hukum internasional. ${ }^{31}$ Perjanjian internasional biasanya mencantumkan ketentuan bagaimana cara untuk mengikatkan diri dalam naskah perjanjian itu sendiri. ${ }^{32}$ Pentingnya ratifikasi Indonesia dapat dilihat dalam kesediaannya untuk secara resmi bergabung dengan upaya regional untuk mengatasi masalah ini, dengan meratifikasi perjanjian ini Indonesia mengakui masalah polusi kabut tidak hanya menjadi masalah domestik, tetapi juga masalah ASEAN yang harus diselesaikan bersama dengan anggota lainnya. ${ }^{33}$

Upaya tersebut merupakan bentuk penerapan dari disaster diplomacy sebagai solusi dari ketegangan yang terjadi, disaster diplomacy melihat kemungkinan perdamaian dan konflik yang terjadi karena adanya bencana. Hal

\footnotetext{
28 Suadela. (2009). Bentuk Pertanggungjawaban Indonesia Terhadap Malaysia Dan Singapura Dalam Masalah Kabut Asap Dipropinsi Riau. Jurnal hukum lingkungan, Fakultas Hukum Universitas Sumatra Utara.hlm 2.

29 Ibid

30 ASEAN Agreement on Transboundary Haze Pollution, Art. 29.

31 J.G Starke, Pengantar Hukum Internasional: Edisi Kesepuluh, terjemahan oleh Bambang Irianan Djajaatmadja, (Jakarta: Sinar Grafika, 2012), hlm. 51

32 Andreas Pramudianto, Hukum Perjanjian Lingkungan Internasional, (Malang: Setara Pers, 2014), hlm. 2.

33 Ibid
} 
penting lainnya dari diplomasi bencna adalah diplomasi bukan mengenai cara untuk memperoleh pemasukan entah itu untuk pemerintah pusat ataupun pemerintah daerah. Diplomasi ini mengenai bagaimana cara agar kita mampu mengubah situasi ${ }^{34}$. Mengubah situasi ini dalam artian, mengubah konstelasi politik yang memanas akibat karhutla menjadi harmonis kembali.

Seiring berjalannya waktu, kasus karhutla selalu terjadi setiap tahunnya, terlebih pada tahun 2019 lalu, Pencemaran udara akibat kebakaran hutan bertentangan dengan prinsip-prinsip hukum lingkungan internasional. Salah satu prinsip adalah "Sie utero tua ut alienum non leades" yang artinya bahwa suatu negara dilarang melakukan kegiatan yang dapat merugikan negara lain, good neighbourliness pada intinya prinsip itu mengatakan kedaulatan wilayah suatu negara tidak boleh diganggu oleh negara lain. Dampak karhutla ini menyebabkan Singapura melakukan protes, hal ini didasarkan pada alasan bahwa kabut asap tersebut telah menimbulkan gangguan terhadap kesehatan masyarakat, perekonomian serta pariwisata mereka. ${ }^{35}$ Dalam kaitannya penyelesaian kasus karhutla ini, Indonesia menolak bantuan dari pemerintah Malaysia dan Singapura, Seperti diberitakan beberapa media Malaysia, Perdana Menteri Malaysia Mahathir Mohamad, mempertanyakan alasan pemerintah Indonesia yang tidak mau menerima bantuan Malaysia untuk memadamkan kebakaran hutan di Indonesia ${ }^{36}$ sehingga kasus karhuta ini menjadi lebih rumit penyelesainnya dan menyebabkan hubungan diplomatik kedua negara naik turun. Dalam kaitannya dengan Disaster diplomacy, menurut Kelman, penolakan bantuan oleh negara penerima justru berpotensi menimbulkan konflik baru, yang dimaksudkan adalah bahwa diplomasi ini dapat mengidentifikasi apakah kegiatan terkait bencana memberi peluang untuk menginduksi kerja sama antara negara-negara atau komunitas-komunitas yang saling bermusuhan. ${ }^{37}$ Adapun penolakan bantuan yang seharusnya diterima dengan sukacita ini, menjadikan Perdana Menteri Malaysia sendiri bertanyatanya di balik penolakan Pemerintah Indonesia. 38

Protes yang dilakukan oleh kedua negara ini, didasari karena Indonesia sebagai negara sumber terjadinya kabut dinilai lamban dalam mengantisipasi kasus karhutla yang hampir selalu terjadi tiap tahunnya. Padahal dalam hal ini, Indonesia telah ikut meratifikasi perjanjian asap lintas batas, hal ini harus menuntut agar cukup untuk mengatasi polusi kabut. Adanya perjanjian ini, bertujuan untuk memaksimalkan upaya lebih besar di antara para pihak dalam mengatasi kabut lintas batas yang berasal dari Indonesia dengan memfasilitasi penyebaran informasi dan dengan memungkinkan Indonesia untuk membentuk Perjanjian berdasarkan pengalamannya sebagai satu-satunya negara sumber utama di kawasan ini.

\footnotetext{
34 Clarke, Arthur C, "An Interview with Ilan Kelman" : Article

35 Asdar / D 10109 519. Transboundary Haze Pollution Di Malaysia Dan Singapura Akibat Kebakaran Hutan Di Provinsi Riau Ditinjau Dari Hukum Lingkungan Internasional.

36 Callistasia Wijaya. "Kebakaran hutan: Ditawari Malaysia dan Singapura bantuan, Indonesia sebut nanti 'dilecehkan, ah gitu aja minta bantuan". Diakses dari https://www.bbc.com/indonesia/indonesia-49765217

37 I Kelman, Disaster Diplomacy: Can Tragedy Help Build Bridges Among Countries?, UCAR Ouarterly Fall, London, 2007, hlm 6.

38Warta Ekonomi. "Tolak Bantuan Malaysia dan Singapura Soal Karhutla Beginiloh Alasan Pemerintah Kita". Diakses dari https://www.wartaekonomi.co.id/read247831/tolak-bantuanmalaysia-dan-singapura-soal-karhutla-begini-loh-alasan-pemerintah-kita
} 
Dilihat dari Dalam kasus transboundary haze pollution, negara yang dirugikan dapat saja menggugat Pemerintah Indonesia karena menurut sejumlah konvensi internasional, seperti Biodiversity Convention dan Climate Change Convention dan ASEAN Agreement on the Conservation of Nature and Natural Resources 1985, dimana memuat ketentuan bahwa negara tetap saja, berkewajiban untuk memastikan bahwa aktivitas tersebut tidak menimbulkan kerusakan di wilayah negara lain (state responsibility). Ketentuan ini bahkan telah menjadi hukum kebiasaan internasional (international customary law) dan mengikat semua negara beradab, bahkan telah diterapkan sejak tahun 1920 dalam kasus Trail Smelter (AS vs Kanada). ${ }^{39}$

Adapun dampak karhutla terhadap hubungan diplomatik antara Indonesia dengan Malaysia dan Singapura yakni, meskipun negara Malaysia dan Singapura menjadi dua negara tetangga yang paling dirugikan, namun kedua negara tersebut tidak membawa permasalahan ini ketingkat Internasional. Meskipun beberapa tahun lalu Singapura pernah membawa kasus karhutla ini ke PBB, namun untuk kasus karhutla selama satu dekade terakhir ini kedua negara lebih memilih mencari jalan melalui penyelesaian dengan disaster diplomacy, baik itu dengan membuat perjanjian mengenai karhutla atau saling membantu menyelesaikan kasus karhutla ini secara bersama-sama. Adapun nota diplomatik yang dikirimkan oleh pemerintah Malaysia dan Singapura, ${ }^{40}$ itu hanya sebagai bentuk keprihatinan atas kasus karhutla yang terjadi di Indonesia. Sehingga bisa dikatakan kasus karhutla ini tidak mempengaruhi terhadap hubungan diplomatik pada sector Kerjasama diplomatik lain, hanya saja baik protes maupun saling tuding tuduhan atas kahutla ini membuat hubungan Indonesia baik dengan Malaysia dan Singapura, cukup renggang pada masa karhutla ini berlangsung. Dikutip dari laman Mata-mata Politik, tertulis bahwa Pemerintah Malaysia telah menyalahkan dan menawarkan bantuan kepada Indonesia, yang sedang bergulat dengan kebakaran hutan di luar kendali di Sumatra dan Kalimantan. Jakarta membantah bertanggung jawab penuh atas kabut asap yang mencekik wilayah itu, meski Pusat Meteorologi Khusus ASEAN menyatakan bahwa sumber kabut asap itu kemungkinan besar berasal dari Indonesia. ${ }^{41}$

\section{Kasus Karhutla Dalam Pandangan Hukum Internasional}

Menurut laporan dari Greenpeace yang dikutip dari laman tirto, menyebut bahwa sampai sekarang belum ada satu pun perusahaan yang membayar ganti rugi atas tuntutan pemerintah. Padahal, jumlah yang harus dibayarkan yakni sebesar Rp18,9 triliun. Perhitungan tersebut diambil berdasarkan sepuluh dari sebelas kasus gugatan perdata pemerintah terhadap perusahaan perkebunan (kelapa sawit, sagu, dan bubur kayu) terkait kebakaran hutan antara 20122015. Mereka adalah PT Kallista Alam (Rp366 miliar), PT Jatim Jaya Perkasa (Rp491 miliar), PT Waringin Agro Jaya (Rp466,5 miliar), PT Waimusi Agroindah

39 A.A.A. Nanda Saraswati.Tranboundary Haze Pollution.Dalam perspektif Hukum Lingkungan Internasional.Studi Kasus. INDONESIA \& ASEAN Makalah Hukum Universitas Indonesia.2010 Hlm 3

40 Victor Maulana. Malaysia Kirim Nota Diplomatik pada Indonesia Soal Kabut Asap. Diakses dari https: / international. sindonews.com/berita/1437202/40/malaysia-kirim-nota-diplomatik-padaindonesia-soal-kabut-asap

41 Tashny Sukumaran. https://www.matamatapolitik.com/kabut-asap-kembali-hubunganindonesia-dan-malaysia-kembali-diuji-in-depth/ 
(Rp29,6 miliar), PT Bumi Mekar Hijau (Rp78,5 miliar), PT National Sago Prima (Rp1,07 triliun), PT Ricky Kurniawan Kertapersada (Rp191 miliar), hingga PT Palmina Utama (Rp22,3 miliar). Ganti rugi paling besar dijatuhkan kepada PT Merbau Pelalawa Lestari terkait pembalakan liar yang dilakukan sejak 2004. Jumlahnya mencapai Rp16,2 triliun. ${ }^{42}$

Kepala Departemen Advokasi Walhi, Zenzi Suhadi, mengatakan bahwa sejauh ini penindakan hukum bagi para pelaku karhutla masih lemah. Kendati sudah dibawa ke pengadilan, pemerintah belum bisa melakukan eksekusi terhadap putusan tersebut. Ketidaktegasan tersebut dapat dilihat pula lewat sikap Jokowi. ${ }^{43}$ Berkali-kali ia mengancam bakal mencopot jabatan kapolda maupun pangdam, berkali-kali pula hal itu menjadi gertak kosong. Tak ada petinggi polri maupun TNI yang pada akhirnya dicopot jabatannya karena gagal mencegah serta mengatasi karhutla. Aspek lain yang perlu dikritisi dari penanggulangan karhutla ialah soal biaya. Pada 2018, anggaran untuk penanggulangan karhutla, seperti yang dialokasikan pada Daftar Isian Pelaksanaan Anggaran (DIPA) Ditjen Pengendalian Perubahan Iklim, sebesar Rp199 miliar: Rp92 miliar untuk pusat sementara sisanya, Rp107 miliar, dialokasikan ke daerah. Tahun ini, anggaran penanggulangan karhutla turun menjadi Rp164 milliar. Angka tersebut jelas tak sebanding dengan realitas. Berdasarkan Kajian Risiko Bencana Kebakaran Hutan dan Lahan terdapat 11 provinsi yang perlu diprioritaskan dalam penanggulangan karhutla. Mereka adalah Riau, Kalimantan Tengah, Kalimantan Barat, Sumatera Selatan, Kalimantan Timur, Jambi, Papua, Lampung, Sumatera Utara, Kalimantan Selatan, hingga Sulawesi Tengah. ${ }^{44}$

Masalah lingkungan hidup yang sering terjadi di indonesia telah menjadikan permasalahan karhutla bukan saja menjadi fokus permasalahan pada tingkat lokal, daerah, pulau atau seluruh bagian negara, tetapi masalah lingkungan itu telah meluas secara transnasional, yakni ketingkat regional dan global. Yang telah menjadi masalah internasional yang sangat popular dan mendesak. 45

Perlindungan lingkungan dipandang sebagai sebuah kepentingan bersama yang dapat diwujudkan jika terdapat kerja sama antar negara dalam lingkup global maupun regional. Pentingnya kerjasama antar negara dalam perlindungan lingkungan juga terdapat dalam Prinsip 27 Deklarasi Rio, yaitu: States and people shall cooperate in good faith and in spirit of partnership in the fulfillment of principles 46 embodied in this declaration and the development of internasional law in the field of sustainable development. Perangkat-perangkat hukum internasional yang mengatur tentang pencemaran lintas batas menggunakan pendekatan global, yaitu suatu pendekatan yang mengutamakan kepentingan bersama ${ }^{47}$ Salah satu rekomendasi konfrensi PBB untuk lingkungan hidup yang mengurusi masalah lingkungan yang disebut Governing Council For 42 Faisal Irfani. Tumpulnya Penegakan Hukum Penyebab Karhutla.
https://tirto.id/tumpulnya-penegakan-hukum-penyebab-karhutla-terulang-eiD3

46 Ibid

47Ida Bagus Wyasa Putara. Hukum Lingkungan Internasional, Perspektif bisnis internasional,Denpasar.2001.hlm.50 
Environmental Programme, tugas lembaga PBB, dibidang lingkungan memberikan saran, dan mengembangkan teknik dan sarana untuk untuk memperhitungkan pertimbangan lingkungan.

Dalam Deklarasi Rio de Janeiro juga merupakan konferensi PBB mengenai lingkungan hidup yang kedua setelah konferensi PBB mengenai lingkungan hidup yang pertama di Stockholm Swedia Tahun 1972. Deklarasi Rio de Janeiro menetapkan serangkaian asas sebagai pedoman di masa yang akan dating, seperti hak-hak manusia atas pembangunan, dan tanggung jawab manusia terhadap pelestarian lingkungan bersama. Kasus karhutla yang terjadi di Indonesia, disebabkan oleh kegiatan manusia dalam kegiatan produksi dan perluasan lahan dengan cara membakar lahan, dimana dapat disimpulkan bahwa kegiatan tersebut sudah menimbulkan kerugian bagi negara lain khususnya Malaysia dan Singapura. Hal yang menarik dalam hal ini adalah, bahwa beberapa pelaku kebakaran hutan di Indonesia adalah diantaranya perusahaan-perusahaan yang berasal dari Malaysia dan Singapura.

Greenpeace Indonesia menemukan setidaknya terdapat empat grup perusahaan yang berkantor di Malaysia dan Singapura terkait dengan kebakaran hutan yang menyebarkan kabut asap di kawasan Asia Tenggara. Mereka adalah IOI, Genting, Kuala Lumpur Kepong dan Bumitama. ${ }^{48}$ Meskipun sebagian besar kebakaran hutan terjadi di Indonesia, mengatasi masalah ini bukan hanya tanggung jawab Indonesia. Dari kebakaran hutan 2019, telah terjadi peningkatan keluhan penyakit pernapasan dan mata di Malaysia sejak September. Badan Nasional Penanggulangan Bencana Indonesia (BNPB) pada bulan September mengumumkan bahwa hampir satu juta orang terdiagnosis infeksi saluran pernapasan akut di daerah yang terkena dampak asap, anakanak dan orang tua adalah kelompok yang paling rentan. 49

Dikutip dalam situs resmi Greenpeace Indonesia, "Banyak dari kebakaran ini terjadi di dekat perkebunan kelapa sawit dan bubur kertas. Beberapa perkebunan kelapa sawit dan bubur kertas besar merupakan milik grup Malaysia dan Singapura," kata Ratri Kusumohartono, Juru Kampanye Hutan Greenpeace Indonesia. Negara-negara ASEAN telah menyetujui Roadmap BebasAsap untuk ASEAN bebas asap lintas batas pada tahun 2020 untuk mengendalikan masalah kabut asap tahunan. Namun ketika tahun 2020 semakin dekat, masyarakat masih tidak melihat tindakan nyata, komitmen dan implementasi yang mampu mengatasi persoalan ini. 50

Perserikatan Bangsa-Bangsa (PBB) memperingatkan bahwa polusi akibat kebakaran hutan dan lahan (karhutla) di Indonesia dapat membahayakan hidup 10 juta anak."Kualitas udara buruk merupakan tantangan bagi Indonesia," ujar wakil Badan Anak PBB (UNICEF) untuk Indonesia, Debora Comini,"Setiap

48 Greenpeace Indonesia."KTT ASEAN Kesempatan Para Pemimpin Menghentikan Masalah Kabut Asap Karhutla Lintas Batas." Diakses dari https://www.greenpeace.org/indonesia/siaranpers / 4128/ktt-asean-kesempatan-para-pemimpin-menghentikan-masalah-kabut-asap-karhutlalintas-batas/

49 Kompas.com, "Hampir Satu Juta Orang Menderita ISPA akibat Kebakaran Hutan dan Lahan", diakses dari https://nasional.kompas.com/read/2019/09/23/17522721/hampir-satu-juta-orangmenderita-ispa-akibat-kebakaran-hutan-dan-lahan.

50Greenpeace Indonesia."KTT ASEAN Kesempatan Para Pemimpin Menghentikan Masalah Kabut Asap Karhutla Lintas Batas." Diakses dari https://www.greenpeace.org/indonesia/siaranpers /4128/ktt-asean-kesempatan-para-pemimpin-menghentikan-masalah-kabut-asap-karhutlalintas-batas/ 
tahun, jutaan anak menghirup udara beracun yang mengancam kesehatan hingga mereka terpaksa bolos sekolah, menyebabkan kerusakan fisik dan kognitif mereka"51. Sehingga bisa dikatakan dalam pandangan hukum internasional, Indonesia bisa saja digugat oleh negara yang terkena dampak dari kasus karhutla tersebut dan bukan hanya negara yang terkena dampak, masyarakat sipil bisa saja melakukan pelaporan ke komisaris Tinggi PBB untuk Hak Asasi Manusia yang mengurusi isu Bisnis dan HAM. Selain itu, masyarakat sipil bisa membuat laporan khusus terkait pelanggaran atas hak Kesehatan. Pernyataan tersebut sesuai dengan pernyataan Yati Andriyani (Koordinator Komisi untuk Orang Hilang dan Korban Tindak Kekerasan) yang dikutip laman CNN Indonesia ${ }^{52}$, dimana menilai bahwa karhutla yang semakin memburuk sepanjang 2019 lalu sudah tergolong dalam kejahatan lingkungan atau ekosida. Dan jika dikaji ulang, alasan Malaysia maupun Singapura tidak membawa karhutla ini ketingkat Internasional, hal ini bisa saja terjadi mengingat hubungan diplomatik yang terlah terjalin cukup lama dan masih eratnya hubungan Kerjasama pada sektor lain menjadikan baik Malaysia maupun Singapura lebih memilih penyelesaian dengan Kerjasama bilateral tanpa melibatkan pihak eskternal.

\section{PENUTUP}

Indonesia dalam kasus karhutla ini cenderung menerapakn disaster diplomacy jangka panjang sebagai upaya penyelesaian konflik, hal ini didasari karena Indonesia, Malaysia, dan Singapura, dan negara ASEAN lain adalah pihak dalam Persetujuan ASEAN tentang Pencemaran Asap Lintas-Batas (Agreement on Transboundary Haze Pollution) yang ditandatangani pada tahun 2002. Dalam perjanjian itu disebut bahwa negara yang membutuhkan bantuan memadamkan api karena kebakaran hutan, bisa meminta bantuan negara anggota ASEAN lainnya yang bersedia membantu. Namun meskipun Indonesia telah ada dalam perjanjian ini, kasus karhutla membuat hubungan antara Indonesia dengan Malaysia dan Singapura tidak harmonis, karena Indonesia menolak bantuan yang diberikan oleh kedua negara tersebut. Menurut Kelman, penolakan bantuan oleh negara penerima justru berpotensi menimbulkan konflik baru.

Dampak dari karhutla yang terjadi di Indonesia terhadap hubungan diplomatik dengan Malaysia dan Singapura ini bisa dikatakan tidak berdampak pada hubungan diplomatik dalam sektor lain, hanya saja menimbulkan perdebatan antara Indonesia dengan Malaysia maupun Indonesia dengan Singapura. Selain itu penanganan kasus karhutla di Indonesia yang masih dianggap lamban menyebabkan citra Indonesia dimata dunia cenderung dipandang sebelah mata.

\footnotetext{
51 CNN Indonesia. "PBB sebut Polusi Karhutla Indonesia Bahayakan 10 Juta Anak". Diakses dari https://www.cnnindonesia.com/internasional/20190924163645-106-433448/pbb-sebut-polusikarhutla-indonesia-bahayakan-10-juta-anak

52 CNN Indonesia. https://www.cnnindonesia.com/nasional/20190916180345-20-430974/koalisimasyarakat-buka-peluang-melaporkan-karhutla-ke-pbb
} 


\section{DAFTAR PUSTAKA}

A.A.A. Nanda Saraswati, (2010).Tranboundary Haze Pollution.Dalam Perspektif Hukum Lingkungan Internasional.Studi Kasus Indonesia \& Asean.Makalah Hukum Universitas Indonesia, 3.

Anih Suryani, (2012). Penanganan Asap Kabut Akibat Kebakaran Hutan Di Wilayah Perbatasan Indonesia. Jurnal DPR, Vol 3, No 1.

Asdar. (2012). Transboundary Haze Pollution Di Malaysia Dan Singapura Akibat Kebakaran Hutan Di Provinsi Riau Ditinjau Dari Hukum Lingkungan Internasional. Jurnal Ilmiah Universitas Tadulako.

Badri, J. (1960). Perwakilan Diplomatik dan Konsuler. Jakarta: Tirtama

Callistasia Wijaya, Kebakaran hutan: Ditawari Malaysia dan Singapura bantuan, Indonesia sebut nanti 'dilecehkan, ah gitu aja minta bantuan, diakses dari https://www.bbc.com/indonesia/indonesia-49765217 pada 2 Agustus 2020.

CNN Indonesia. PBB sebut Polusi Karhutla Indonesia Bahayakan 10 Juta Anak. Diakses

https://www.cnnindonesia.com/internasional/20190924163645-106-

433448/pbb-sebut-polusi-karhutla-indonesia-bahayakan-10-juta-anak

CNN Indonesia. Koalisi Masyarakat Buka Peluang Melaporkan Karhutla ke PBB. Diakses dari https://www.cnnindonesia.com/nasional/2019091618034520-430974/koalisi-masyarakat-buka-peluang-melaporkan-karhutla-ke-pbb

Deny Bram. Pertanggungjawaban Indonesia Terhadap Pencemaran Kabut Asap Di kawasan Asean (Peodekatan Economic Analysis Of Law). VOL 40, NO 4 (2010)

Elin Yunita Kristanti, Masa Depan Hubungan RI-Singapura Menurut Menlu Singapura. diakses dari https://www.liputan6.com/global/read/3121144/masa-depan-hubunganri-singapura-menurut-menlu-negeri-singa Pada 2 Agustus 2020.

Greenpeace Indonesia. 2015a. Greenpeace Mengekspos Hutan Gambut Terbakar yang Ditanami Kelapa Sawit, diakses dari http://www.greenpeace.org/seasia/id/press/releases/Greenpeacemengeksposhutan-gambut-terbakar-yang-ditanami-kelapa-sawit/ Pada 12 Agustus 2020.

Greenpeace Indonesia, Briefer - Krisis Kebakaran Hutan dan Lahan di Indonesia: Perusahaan Kelapa Sawit dan Bubur Kertas dengan Area Kebakaran Terbesar Tak Tersentuh Hukum diakses dari https://www.greenpeace.org/indonesia/publikasi/3795/briefer-krisiskebakaran-hutan-dan-lahan-di-indonesia-perusahaan-kelapa-sawit-danbubur-kertas-dengan-area-kebakaran-terbesar-tak-tersentuh-hukum/ Pada 1 Februari 2020 Pukul 21.00 WIB.

Greenpeace Indonesia. KTT ASEAN Kesempatan Para Pemimpin Menghentikan Masalah Kabut Asap Karhutla Lintas Batas. Diakses dari: https://www.greenpeace.org/indonesia/siaran-pers/4128/ktt-aseankesempatan-para-pemimpin-menghentikan-masalah-kabut-asap-karhutlalintas-batas /

Hermawan, W. 2006. Dampak Kebakaran Kebun dan Lahan terhadap Lingkungan Hidup. Dinas Perkebunan Provinsi Kalimantan Barat.

Ida Bagus Wyasa Putara. (2011). Hukum Lingkungan Internasional, Perspektif bisnis internasional. Universitas Sudayana. 
Kunto Arief Wibowo,(2019). Manajemen Penanganan Kebakaran Hutan dan Lahan (Karhutla) Guna Peningkatan Ekonomi Kerakyatan. Jurnal Studi Sosial dan Politik, Vol. 3, No. 1.

Kompas.com, Hampir Satu Juta Orang Menderita ISPA akibat Kebakaran Hutan dan Lahan, diakses dari https://nasional.kompas.com/read/2019/09/23/17522721/hampir-satujuta-orang-menderita-ispa-akibat-kebakaran-hutan-dan-lahan. Pada 12 Agustus 2020.

Loade Muhamad Fathun, (2016). Bencana Hutan dalam Hubungan Internasional. Andalas Journal of International Studies, Vol.5 No.1

Liputan 6, Kabut Asap Memanaskan Hubungan Diplomatik Indonesia dan Malaysia?, diakses dari https://www.liputan6.com/news/read/4062487/kabut-asap-

memanaskan-hubungan-diplomatik-indonesia-dan-malaysia. Pada 25 Juni 2020.

Maksum,A \& Bustami, R. (2014). Ketegangan hubungan Indonesia Malaysia dalam isu Tarian Pendet,Kajian Malaysia. Kajian Malaysia: Journal of Malaysian Studies.

N.H.T. Siahaan. (1986). Ekologi Pembangunan Dan Hukum Tata Lingkungan,Jakarta.: Erlangga

Suadela. (2009). Bentuk Pertanggungjawaban Indonesia Terhadap Malaysia Dan Singapura Dalam Masalah Kabut Asap Dipropinsi Riau. Jurnal hukum lingkungan, Fakultas Hukum Universitas Sumatra Utara.

Sugiyono. (2014). Metode Penelitian Kuantitatif Kualitatif dan $R \& D$. Bandung : Alfabeta.

Suryokusumo, Sumaryo. (2013). Hukum Diplomatik dan Konsuler Jilid I. Jakarta : Tatanusa

Victor Maulana. Malaysia Kirim Nota Diplomatik pada Indonesia Soal Kabut Asap. Diakses dari https:/ / international.sindonews.com/berita/1437202/40/malaysia-kirimnota-diplomatik-pada-indonesia-soal-kabut-asap

Warta Ekonomi. "Tolak Bantuan Malaysia dan Singapura Soal Karhutla Beginiloh Alasan Pemerintah Kita". Diakses dari https://www.wartaekonomi.co.id/read247831/tolak-bantuan-malaysiadan-singapura-soal-karhutla-begini-loh-alasan-pemerintah-kita 